\title{
HUBUNGAN KONSENTRASI DAN PERSEPSI KINESTETIK TERHADAP KEMAMPUAN SHOOTING PADA PEMAIN U-11 TAHUN RAGUNAN SOCCER SCHOOL
}

\author{
Albert Lisa Hutabarat \\ Ferry Yohannes Watimena dan Nur Fitranto
}

\begin{abstract}
ABSTRAK. Penelitian ini bertujuan untuk mengetahui hubungan konsentrasi dan persepsi kinestetik terhadap kemampuan shooting pada pemain U-11 tahun Ragunan Soccer School, Penelitian ini dilaksanakan pada bulan Juli tanggal 9 Juli 2017 di Lapangan Sepakbola GOR Ragunan, Jakarta Selatan. Dengan menggunakan metode survey yaitu teknik korelasi dengan cara mengukur Konsentrasi dengan tes Grid Concentration Exercise, persepsi kinestetik dengan tes persepsi kinestetik untuk shooting, dan kemampuan shooting dengan tes kemampuan shooting. Ketiga data yang dikumpulkan tersebut kemudian dikorelasikan dengan menggunakan teknik korelasi sederhana. Populasi dalam penelitian ini adalah pemain U-11 tahun Ragunan Soccer School untuk dijadikan sampel dengan jumlah 20 orang dengan teknik purposive sampling. Teknik pengajuan hipotesis dilakukan dengan menggunakan teknik analisis statistika korelasi sederhana dan korelasi ganda menggunakan uji $r$ dengan taraf signifikan $\alpha=0,05$ dan nilai $\mathrm{n}=20$ diperoleh rtabel $=0.433$. Berdasarkan hasil analisis dalam penelitian ini maka diperoleh koefisien $(r X 1 y)=0,505$ dengan thitung sebesar 2,483 dan ttabel sebesar 1,734. Karena thitung > ttabel maka terdapat hubungan positif konsentrasi dengan kemampuan shooting. Sedangkan untuk persepsi kinestetik dengan kemampuan shooting diperoleh nilai koefisien $(r X 2 y)=0,722$ dengan thitung sebesar 4,428 dan ttabel sebesar 1,734. Karena thitung $>$ ttabel maka terdapat hubungan positif. Kedua variabel secara bersama-sama diperoleh nilai koefisien korelasi $(r X 1-2)=$ ii 0,7148 dengan Fhitung sebesar 8,793 dan F tabel sebesar 3,59. Karena Fhitung > Ftabel maka terdapat hubungan konsentrasi dan persepsi kinestetik dengan kemampuan shooting. Uji koefisien determinasi $r X 1 y 2$ sebesar $25,50 \%$ yang berhubungan dengan hasil kemampuan shooting, koefisien determinasi untuk $r 2 x 2 \mathrm{y}$ sebesar $52,13 \%$ yang berhubungan dengan hasil kemampuan shooting, koefisien determinasi untuk $r 2 y 1-2$ sebesar $51,10 \%$ sedangkan $48.90 \%$ merupakan faktor lainnya yang berhubungan dengan hasil kemampuan shooting. Berdasarkan hasil analisa data tersebut, maka hasil penelitian ini dapat disimpulakan terdapat hubungan positif antara konsentrasi dengan hasil kemampuan shooting, terdapat hubungan positif antara persepsi kinestetik dengan kemampuan shooting dan terdapat hubungan positif secara bersamasama antara konsentrasi dan persepsi kinestetik terhadap kemampuan shooting pada pemain U-11 tahun Ragunan Soccer School.
\end{abstract}

\section{Kata Kunci : Konsentrasi, Persepsi Kinestetik, Shooting,}

\section{PENDAHULUAN}

Olahraga adalah salah satu aktivitas fisik maupun psikis seseorang yang berguna untuk menjaga dan meningkatkan kualitas kesehatan setiap individu. Pada era ini, terdapat berbagai jenis olahraga, salah satu contoh olahraga yaitu sepak bola. Sepak bola merupakan salah satu cabang olahraga yang sangat popular dan digemari oleh sebagian besar lapisan masyarakat di seluruh penjuru dunia. Olahraga ini semakin diminati oleh banyak orang karena dapat dinikmati serta dimainkan oleh anakanak hingga orang dewasa. Sepak bola adalah cabang olahraga yang dimainkan oleh 11 orang pemain pada setiap tim yang membutuhkan kerja sama tiap pemain. Kerja sama tim yang baik akan menghasilkan permainan yang baik pula, sehingga dapat meningkatkan prestasi suatu tim.

Dewasa ini sepakbola dimainkan bukan sekedar hiburan atau pengisi waktu senggang, akan tetapi para pemain dan 
pelatihnya diharapkan untuk berprestasi setinggi-tingginya. Prestasi yang tinggi hanya dapat dicapai dengan latihan-latihan yang direncanakan dengan baik dan dilakukan secara terus menerus. Hal ini sangatlah wajar, karena sepakbola sudah dipertandingkan baik ditingkat daerah, nasional maupun internasional sejak lama.

Berdasarkan hasil observasi yang dilakukan di Ragunan Soccer School diperoleh informasi bahwa hasil kemampuan shooting pemain u-11 tahun yang berjumlah 20 pemain tergolong rendah. Kemudian setelah dilakukan observasi dan pengamatan serta penilaian secara objektif oleh penulis pada hasil latihan teknik shooting pemain u-11 tahun masih banyak yang belum bisa melakukan teknik shooting yang baik dan benar. Pemain masih banyak yang tidak tepat sasaran saat melakukan kemampuan teknik shooting. Hal ini dikarenakan masih banyak pemain yang belum menguasai teknik shooting.

Hal tersebut merupakan suatu pertanda bahwa kemampuan shooting pemain u-11 tahun masih rendah. Setiap pemain dituntut untuk mengembangkan kemampuannya demi mencapai prestasi tim yang baik. Hal tersebut dikarenakan dalam sepak bola bukan hanya kerja sama tim saja yang dibutuhkan tetapi juga kualitas individu tiap pemain menjadi faktor utama dalam keberhasilan suatu tin sepak bola.

Salah satu yang mempengaruhi kemampuan pemain yaitu konsentrasi individu. Seorang pemain sepak bola gagal memasukkan bola dari titik penalti karena saat menendang ia kehilangan konsentrasi. Dengan demikian, dapat dikatakan bahwa konsentrasi merupakan hal dasar yang sangat penting dan perlu untuk dilatih oleh setiap pemain sepak bola. Konsentrasi merupakan kemampuan olahragawan dalam memelihara fokus perhatiannya dalam lingkungan pertandingan yang relevan.

Konsentrasi memegang peranan penting bagi seorang anak untuk mengingat, merekam, melanjutkan, dan mengembangkan materi yang diperoleh dari pelatih. Kemampuan untuk mengingat, merekam, dan mengembangkan materi yang baik memungkinkan anak memperoleh prestasi yang optimal. Pada pemain $\mathrm{u}-11$, pemain sering melakukan kesalahan-kesalahan yang seharusnya tidak terjadi, salah satunya seperti shooting yang tidak akurat. Saat diberikan instruksi atau petunjuk pelaksanaan sesi latihan, pemain u-11 sering berbicara kepada temannya, hal itu menyebabkan perhatian pada pelatih berkurang, sehingga pada saat melakukan sesi latihan banyak kesalahan yang terjadi.

$$
\text { Jadi dalam melakukan }
$$

tendangan atau shooting pemain harus dapat merasakan gerakan yang dilakukannya sehingga akan dapat menghasilkan gol. Jadi, dalam melakukan tendangan atau shooting dibutuhkan suatu perasaan dan kesadaran akan posisi tubuh pada waktu bergerak atau persepsi kinestetik. Dengan kata lain, kesempurnaan akan suatu teknik biasanya hanya bisa dilakukan oleh pemain yang cepat mendeteksi suatu pola gerakan dan pemain tersebut biasanya memiliki persepsi kinestetik yang baik. Dari seluruh uraian yang telah dipaparkan di atas, tampaknya dapat diasumsikan bahwa tedapat hubungan yang sangat erat antara kemampuan shooting dengan beberapa unsur penting seperti aspek konsentrasi dan persepsi kinestetik.

Namun, untuk dapat membuktikan apakah aspek-aspek tersebut memiliki hubungan yang saling terkait satu sama dengan lainnya akan dapat ditentukan dengan suatu pendekatan ilmiah melalui suatu penelitian yang relevan dan akurat. Untuk itu maka akan dilakukan penelitian tingkat konsentrasi dan persepsi kinestetis terhadap kemampuan shooting pemain u-11 tahun. Penelitian ini berjudul "Hubungan Konsentrasi dan Persepsi Kinestetis Terhadap Kemampuan Shooting Pemain U11 Tahun Ragunan Soccer School".

\section{KONSENTRASI}

Seseorang yang ingin memperoleh kesuksesan harus mampu berkonsentrasi dengan baik untuk memperoleh tujuannya itu, begitu juga dengan dunia olahraga, konsentrasi merupakan hal yang mutlak dibutuhkan. Memusatkan perhatian atau berkonsentrasi memang merupakan hal yang sangat sulit untuk dilakukan. 
Konsentrasi sangat dibutuhkan terutama cabang olahraga yang menuntut konsentrasi tinggi salah satunya olahraga sepakbola sebab olahraga ini membutuhkan ketepatan dan konsistensi, pada setiap tindakan yang diambil. Schmid, Peper, dan Wilson dalam

Komarudin menjelaskan bahwa konsentrasi adalah kemampuan untuk memusatkan perhatian pada tugas dengan tidak terganggu dan terpengaruhi oleh stimulus yang bersifat eksternal maupun internal. Nideffer juga mengungkapkan bahwa konsentrasi adalah perubahan yang konstan yang berhubungan dengan dua dimensi, yaitu dimensi luas (width) dan dimensi pemusatan (focus). Selain itu, Siswanto menyebutkan bahwa yang dimaksud konsentrasi yaitu kemampua untuk memusatkan perhatian secara penuh pada persoalan yang sedang dihadapi.

Sedangkan stimulus internal adalah stimulus yang berasal dari dalam diri seseorang, seperti rasa gugup, dan terlalu cemas. Menurut Loehr dalam Komarudin, atlet dikatakan memiliki konsentrasi apabila:"We have the right when what we are doing is the same as what we are thinking" Uraian tersebut berarti seseorang dikatakan berkonsentrasi ketika apa yang dilakukan sama dengan apa yang dipikirkannya. Pendapat tersebut jelas bahwa adanya kesamaan apa yang dilakukan dengan apa yang dipikirkan, menunjukan bahwa atlet memiliki konsentrasi.

Dengan demikian, konsentrasi merupakan kemampuan yang sangat sulit untuk dikuasai oleh atlet karena perhatian yang ada dalam pikiran atlet seringkali berubah yang dipenaruhi oleh stimulus baru. Oleh sebab itu, konsentrasi perlu dilatih kepada atlet, sebab apabila tidak dilatih maka akan cenderung gagal dalam mengembangkan kemampuan konsentrasinya, dan bersamaan denfan hal itu altet akan mengalami kegagalan dalam setiap pertandingan yang diikutinya. Sumber pengacau konsentrasi dari stimulus, yakni visual, kinestetik, dan auditory.

Nugroho mengungkapkan bahwa terdapat tujuh aspek-aspek konsentrasi yaitu sebagai berikut:
1) Pemusatan pikiran. Yaitu suatu keadaan belajar yang membutuhkan ketenangan, nyaman, perhatian seseorang dalam memahami isi pelajaran yang dihadapi.

2) Motivasi. Yaitu keinginan atau dorongan yang terdapat dalam diri individu untuk berusaha mengadakan perubahan tingkah laku yang lebih baik dalam memenuhi kebutuhannya.

3) Rasa kuatir. Yaitu perasaan yang tidak tenang karena seseorang merasa tidak optimal dalam melakukan pekerjaannya.

4) Perasaan tertekan. Yaitu perasaan seseorang yang bukan dari individu melainkan dorongan atau tuntutan dari orang lain maupun lingkungan.

5) Gangguan pemikiran. Yaitu hambatan seseorang yang berasal dari dalan individu maupun orang sekitar. Misalnya masalah ekonomi, keluarga, mauppun masalah pribadi individu.

6) Gangguan kepanikan. Yaitu hambatan untuk berkonsentrasi dalam bentuk rasa was-was menunggu hasil yang akan dilakukan maupun yang sudah dilakukan oleh orang tersebut.

7) Kesiapan belajar. Yaitu seseorang yang sudah siap ajkan menerima materi, sehingga individu dapat mengembangkan potensi yang dimilikinya.

Gangguan visual berupa barang atau benda yang bergerak, besar, dan warnanya mencolok. Gangguan auditory berupa suara dari superter dan cerita mengenai lawan bertanding. Gangguan kinestetik merupakan semua hal yang dirasakan atau dilakukan, seperti kelelahan fisik, kelelahan mental, ada atau tidak adanya pelatih/orang yang dicintai ketika pertandingan, lingkungan bertanding, dan peralatan bertanding. Hal ini menandakan bahwa altet kurang dapat berkonsentrasi apabila individu tersebut mengalami perhatian yang tepecah-pecah. Hal ini sangat berbahaya ketika atlet dalam situasi sebuah pertandingan, dimana ketika dalam pertandingan dituntut untuk memberika yang terbaik untuk timnya.

Oleh karena itu konsentrasi yang baik sangat dibutuhkan oleh setiap atlet. Adapaun ciri-ciri atau karakterikstik atlet yang sedang berkonsentrasi adalah tertuju pada objek/benda pada saat itu, 
perhatiannya tetap pada objek tertentu dan tidak ada perhatian atau pemikiran pada objek lain, serta mampu menenangkan dan memperkuat mental. Berikut adalah alur atau proses terjadinya konsentasi.

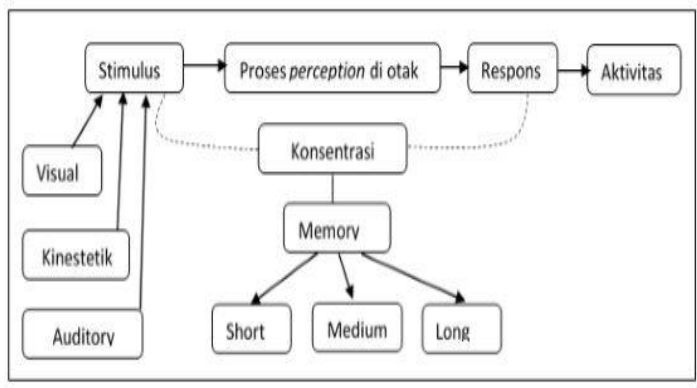

Gambar 1. Alur atau Proses Terjadinya Konsentrasi

Konsentrasi yang efektif adalah suatu proses terfokusnya perhatian seseorang secara maksimal terhadap suatu objek kegiatan yang dilakukan dan proses tersebut terjadi secara otomatis serta mudah karena orang yang bersangkutan mampu menikmati kegiatan yang sedang dilakukannya. Hal ini berarti bahwa apabila seorang atlet memiliki konsentrasi yang efektif ketika mampu memfokuskan perhatiannya secara maksimal kepada kegiatan yang sedang dilakukannya, hal tersebut dikarenakan karna seseorang tersebut mampu menikmati kegiatan yang sedang dilakukannya.

\section{PERSEPSI KINESTETIK}

Kesuksesan dalam suatu penampilan sangat sering tergantung kepada seberapa besar efektifnya pelaku dalam mendeteksi, merasa, dan menggunakan informasi sensori yang sesuai. Sumber informasi didapat dari beberapa sumber dasar yang terdiri informasi yang berasal dari luar (eksteroceptive) dan informasi dari dalam (proprioceptive).

Berdasarkan struktur bahasa, kinestetik diterjemahkan dari kata kinestethetic yang artinya berhubungan dengan kinesihesia yang berasal dari kata kines atau kinesis yang mengandung arti gerakan, dan thesis atau asthesia yang artinya merasakan. Hal ini sejalan dengan Oxedine yang menyatakan bahwa kinestetik seringkali menunjuk pada indera otot (muscle sense) atau indera motorik (motor sense). Persepsi berasal bahasa Latin yaitu perceptio, percipio yang berarti tindakan menyusun, mengenali, dan menafsirkan informasi sensoris guna memberikan gambaran dan pemahaman tentang lingkungan.

Persepsi meliputi semua sinyal dalam sistem saraf yang merupakan hasil dari stimulasi fisik atau kimia dari organ pengindra. Dengan demikian, pernyataan tersebut menyiratkan pengertian bahwa persepsi kinestetik mengarah kepada kemampuan tubuh di dalam mempresepsi atau merasakan gerakan tubuh sehingga tidak jarang perspesi kinestetik disebut juga dengan indra kinestetik (kinesthetics sense) yang berarti suatu fungsi dari organ-organ tubuh yang erat hubungannya dengan posisi atau gerak tubuh. Kesuksesan dalam suatu penampilan sangat sering tergantung kepada seberapa besar efektifnya pelaku dalam mendeteksi, merasa, dan menggunakan informasi sensori yang sesuai.

Proprioceptive yang merupakan informasi dari gerakan tubuh. Proprio yang menggambarkan informasi dari dalam tubuh.seperti dari posisi sendi,kekuatan otot, orientasi di dalam ruang misalnya keadaan terbalik dan sebagainya. Bentukbentuk informasi yang serupa sering disebut dengan kinesthesis atau proprioceptive. Pada berbagai sumber kedua instilah tersebut disamakan. Frank Pyke menyatakan bahwa "persepsi kinestetik adalah kecakapan untuk merasakan posisi, usaha dan gerakan tubuh atau bagian bagian tubuh, dan kadang-kadang disebut juga sebagai indera keenam". Disebut sebagai indera keenam sebab merupakan tambahan pertama yang dikenal setelah lima indera yang secara konvensional telah diakui sebelumnya yaitu,penglihat, pendengar, penciuman, perasa, dan peraba. Mengingat posisi persepsi kinestetik sebagai indera keenam, maka yang sangat penting artinya adalah bagaimana tubuh dapat mempresepsi posisi dan gerakan baik yang dilakukan oleh bagian-bagian tubuh secara parsial maupun yang dilakukan oleh tubuh secara keseluruhan. 
Persepsi kinestetik adalah kecakapan untuk merasakan gerakan tubuh terpisah dari alat-alat visual atau auditori atau dalam terminologi populer disebut merasakan gerak tubuh. Semakin tinggi tingkat kepekaan indera tersebut akan semakin meningkatkan kemampuan untuk merasakan posisi maupun mengendalikan gerakan-gerakan tubuh. Harsono menyatakan bahwa persepsi kinestetik adalah indera yang memberikan kesadaran tentang posisi tubuh atau bagian-bagian tubuh pada waktu bergerak Lebih lanjut dinyatakan juga bahwa karena indera tersebut, maka seseorang akan dapat mengontrol derakan-gerakan dengan lebih akurat. Hal ini mengandung arti bahwa kemampuan tubuh dalam hal merasakan posisi maupun mengendalika gerakangerakan atau menentukan besarnya intensitas kerja otot secara sadar dan tepat, baik yang dilakukan oleh bagian-bagian tubuh secara parsial maupun yang dilakukan oleh tubuh secar a keseluruhan.

Dengan kata lain bahwa kemampuan tubuh dalam merasakan posisi dan menentukan intesitas kerja otot akan semakin meningkat apabila dibarengi oleh kinestetik yang dimiliki oleh seseorang. Bahkan lebih luas dari itu, dengan memiliki persepsi kinestetik yang baik di samping akan memiliki kemampuan merasakan posisi dan mengendalikan gerakan atau menentukan besarnya intensitas kerja otot. Juga secara simultan disertai dengan kemampuan melakukan penyesuaian terhadap ruang dan benda-benda yang ada di sekelilingnya. Senada dengan itu dinyatakan pula bahwa persepsi kinestetik adalah kemampuan untuk merasakan posisi tubuh dalam ruang dan hubungan antar bagian-bagian tubuh. Memperkuat hal tersebut Davis menyatakan bahwa persepsi kinestetik adalah perasaan yang menunjukkan gerakan atau awal kontraksi dari otot, tendon dan persendian.

\section{KEMAMPUAN SHOOTING}

Sepakbola merupakan cabang olahraga yang sangat terkenal dan digemari oleh semua lapisan masyarakat. Dewasa ini sepakbola dimainkan bukan sekedar hiburan atau pengisi waktu senggang, akan tetapi para pemain dan pelatihnya diharapkan untuk berprestasi setinggitingginya. Prestasi yang tinggi hanya dapat dicapai dengan latihan-latihan yang direncanakan dengan baik dan dilakukan secara terus menerus. Permainan sepakbola merupakan cabang olahraga permainan beregu atau tim. Suatu tim akan dapat menyajikan permainan yang menarik apabila tim tersebut memiliki kekompakan, artinya kerjasama antar pemain dalam satu tim tersebut dapat berjalan lancar, hal ini dapat dilakukan apabila setiap pemain dapat menguasai beberapa teknik dasar dalam permainan sepakbola.

Dari sudut pandang penyerangan, tujuan sepakbola adalah melakukan shooting ke gawang. Seorang pemain harus menguasai kemampuan dasar menendang bola dan salanjutnya mengembangkan sedertana teknik shooting yang memungkinkannya melakukan tendang shooting dan mencetak gol dari berbagai posisi di lapangan.

Menendang bola dapat dilakukan dari berbagai situasi yang terjadi pada saat pertandingan berlangsung, seperti untuk memulai setiap babk maka disebut tendangan permulaan (kick-of), tendangan yang dilakukan dalam kerja sama antar permain yang disebut tendangan operan/umpan (passing), menendang bola yang diarahkan ke gawang dalam usaha mencetak gol disebut tendangan menembak (shooting), dan tendangan yang dilakukan setelah terjadi suatu pelanggaran yang dilakukan oleh para pemain disebut tendangan bebas tidak langsung dan tendangan hukuman bebas langsung.

Dengan artian bahwa tendangan bebas tidak langsung bola harus bola harus menyentuh lebih dari satu orang pemain baru bisa menghasilkan gol, sedangkan untuk tendangan bebas langsung gol tercipta dari tendangan yang dilakukan, seperti tendangan bebas dari titik penalti. Seorang pemain yang muda biasanya melakukan shooting dari dekat gawang. Ketika kemampuan seorang pemain semakin meningkat, dia harus mulai melakukan shooting lebih jauh dari gawang. Sebagai aturan umum, untuk melakukan shooting pemain harus mencapai daerah 
pinalti, jika mereka memang dalam posisi terbuka.

Menendang bola adalah salah satu karakteristik permainan sepakbola yang paling dominan. Tujuan menendang bola adalah untuk Menedang Bola atau Shooting dan menendang ke arah gawang (shooting at the goal).

\section{1) Menedang Bola atau Shooting}

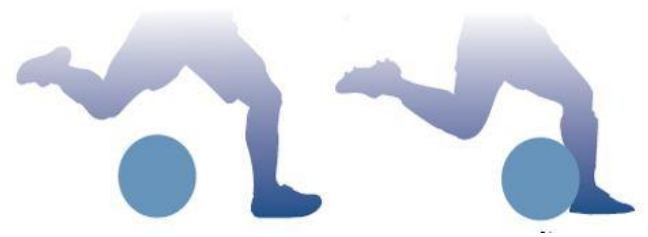

Gambar 2. Menendang Bola

Tindakan memberi bola kepada rekan satu tim. Teknik ini merupakan bagian sangat penting dalam konsep bermain, umpan memungkinkan sebuah tim untuk:

- Tetap menguasai bola,

- Merancang serangan

- Mengubah arah permainan

- Serangan balik

-Menyediakan umpan akhir yang menentukan.

Umpan silang adalah tipe dari umpan pendek maupun umpan panjang, biasanya mengawali terjadinya tembakan ke gawang. Umpan silang ini biasanya berfungsi sebagai umpan akhir.

2) Menendang ke gawang / shots on goal

Menendang bola merupakan tugas gerakan kemampuan yang bersifat khusus yang memiliki karakteristik yang bersifat spesifik. Pengembangan kemampuan gerak menendang bola perlu memahami karakteristik dan klasifikasi gerakan menendang bola. Tindakan ini bertujuan untuk mengirim bola masuk ke gawang lawan. Ini adalah puncak dari sebuah serangan dan inti dari permainan sepakbola.

Shooting membutuhkan kualitas teknis (menembak dengan benar, akurasi), kualitas fisik (power, koordinasi, keseimbangan) dan kualitas mental (determinasi, keberanian, kepercayaan diri). Dengan kata lain, melalui hasil dari shooting sebuah tim dapat meraih kemenangan atau kekalahan. Hal itu dikarenakan skor yang akan diperoleh oleh sebuah tim ditentukan melalui seberapa banyak sebuah tim dapat memasukan bola ke gawang lawan dan hal itu membutuhkan sebuat teknik shooting yang sangat baik.

Menendang bola mempunyai dua arah putaran, menurut Soekatamsi menjelaskan arah putaran jalannya bola ada dua macam, yaitu: a) Tendangan lurus (langsung). Bola setelah ditendang tidak berputar sehingga bola melambung lurus dan jalannya kencang, tenaga tendangan melalui titik pusat bola, keluar menuju lintasan bola (lurus). b) Tendangan melengkung (slice). Bola setelah ditendang berputar ke arah yang berlawanan, bila bola melambung setelah sampai puncak akan turun vertikal.

Pada tendangan melengkung ini tenaga tendangan tidak melalui titik pusat bola, tenaga tendangan menyinggung bola dan memutar bola sehingga lintasan bola melengkung atau berupa garis lengkung sesuai dengan arah putaran bola. Hal tersebut berarti tendangan tidak semestinya lurus ada beberapa teknik tendangan yang melengkung, sama seperti yang telah dijelaskan sebelumnya. Shooting adalah salah satu kemampuan individu dalam permainan sepakbola dengan tujuan memasukan bola ke dalam gawang. Teknik dasar menendang bola dengan kaki kurakura penuh biasa digunakan para pemain sepakbola dengan tujuan untuk memasukan bola ke dalam tiang gawang.

Terdapat beberapa tahapan-tahapan untuk melakukan shooting yang baik dan benar. Berikut adalah tahapan-tahapannya

a) Tahapan Persiapan

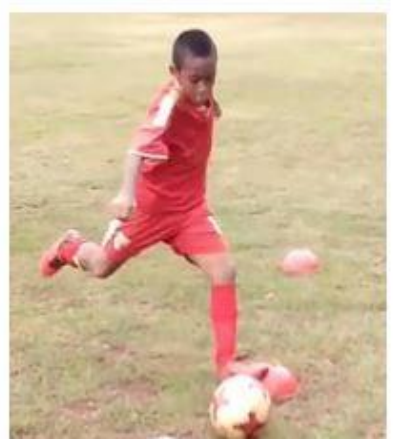

Gambar 3. Tahapan Persiapan (Sumber: Dokumentasi Pribadi) 
- Dekati bola dari belakang pada sudut yang tipis.

-Letakkan kaki yang menahan keseimbangan di samping bola.

- Tekukan kaki tersebut.

- Rentangkan tangan ke samping untuk menjaga keseimbangan.

- Tariklah kaki yang akan menendang ke belakang.

- Luruskan kaki tersebut.

- Kepala tidak bergerak.

- Fokuskan perhatian kepada bola

b) Tahapan Pelaksanaan

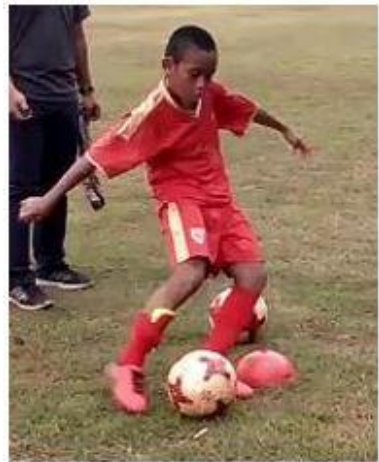

Gambar 4. Tahapan Pelaksanaan

(Sumber: Dokumentasi Pribadi)

- Luruskan bahu dan pinggul dengan target.

- Tubuh di atas bola.

- Sentakan kaki yang akan menendang sehingga lurus.

- Jaga agar kaki tetap kuat.

- Tendangan bagian tengah bola dengan instep (tendangan shooting)

c) Tahapan Follow Through

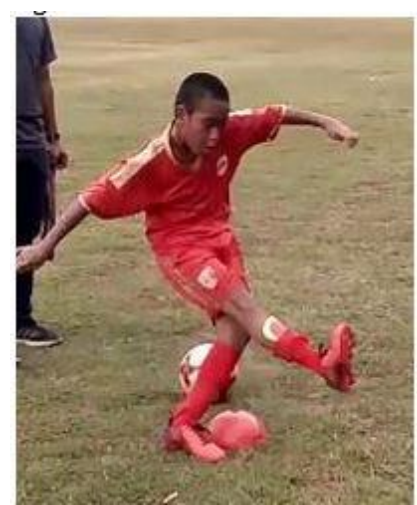

Gambar 5. Tahapan Follow Through

(Sumber: Dokumentasi Pribadi)
- Daya gerak ke depan melalui kontak.

- Sempurnakan gerakan akhir dari kaki yang menendang.

- Kaki yang menahan keseimbangan terangkat dari permukaan lapangan atau tanah

\section{ANATOMI DAN ANALISIS BIOMEKANIKA SAAT SHOOTING}

Dalam melakukan gerakan shooting bukan hanya dilakukan oleh bagian otot tungkai saja yang melakukan gerakan akan tetapi tangan juga melakukan gerakan tapi hanya berayun untuk menjaga keseimbangan dan keserasian gerak pada saat melakukan shooting. Untuk melakukan shooting otot yang bergerak adalah oto bagian-bagian bawah. Otot bagian bawah secara umum itu adalah (a) m. Tibialis Anterior, (b) m. Extensor hallusis longus (c) $\mathrm{m}$. Etensor digitorum longus (d) $\mathrm{m}$. Peronis tersiuse (e) m. Gastrocnemius ( $f$ ) $m$. Soleus $(g) m$. Plantaris (h) $m$. Pepleteus (i) $m$. Tibialis posterior (j) $m$. Pereneus brevis. Berikut gambar jelas bagian otot tungkai bawah yang digunaan untuk melakukan gerakan shooting
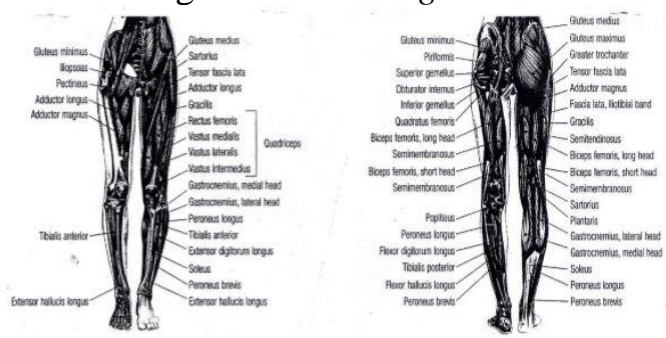

Gambar 6 Otot Tungkai Bagian Bawah

(Sumber: Frederic delavier, Strength

Training Anatomy, Second Edition, Human kinectics, 2006, h. 93)

Dari penjelasan tersebut, untuk melakukan gerakan shooting pada saat melakukan ancang-ancang, persedian bergerak dimulai dari gerakan fleksi ke persendian lutut dan panggul serta engkel kaki kanan yang terangkat ke atas.

Sedangkan pada saat menendang kaki kiri menahan, begitu juga seterusnyahingga pergantian langkah kaki. Ketika kaki kiri berhenti, maka akan terjadi 
penahanan berat badan pada kaki kiri, yang didukung oleh otot-otot hamstring, quadriceps, gluteus, gastronocmeus. Berat badan akan ditanggung seluruhya oleh kaki kiri. Kaki kiri dalam menahan berat bada sedikit dibengkokkan agar mendapat jangkauan kaki kanan pada bola. Sehingga perkenaannya sesuai dengan yang diinginkan pandangan sebelum tendangan dikonsentrasikan ke bola sedangkan ketika hampir menyentuh bola lihatlah sasaran yang akan dituju. Pada saat menendang bola dengan kaki kanan maka poros pertama persendian terdapat pada pinggul.

Lutut sedikit fleksi yang digerakkan oleh kelompok otot hamstring yang juga ikut mengambil ancang-ancang dan sendi engkel lurus ekstensi yang dikontraksikan oleh otot-otot betis.

Pada saat pergerakan menarik kaki tendangan dari belakang yang bertugas adalah otot iliacus, anterior sup, ili spine, tensor fasciae latae atau kelompok quadriceps extensor bagian froximal. Sedangkan pada saat ekstensi lutut digerakkan oleh rectus femoris, vastus medialis, vastus lateralis, atau kelompok quadriceps bagian distal. Pada saat gerak follow through, otot rileks dan menepakkan kaki sebagai gerak lanjutan untuk menghindari resiko cidera. Proses analisis biomekanika pada saat melakukan ayunan gerakan pada saat melakukan shooting meliputi :

a. Consentric, otot yang memendek dan menjadi tebal atau kedua ujungnya saling mendekat. Dimana jenis kontraksi otot ini terjadi pemendekan otot yang bertujuan untuk menghasilkan akselerasi pada tubuh contohnya lari sprint.

b. Isometric, tensi otot diimbangi beban atau tahanan kaki tanpa ada tegangan otot tanpa gerak. Kontraksi ini merupakan kontraksi otot bagian otot dikontraksikan tanpa terjadinya gerakan pada sendi dan tanpa gerakan anggota tubuh dengan gerakan seperti mendorong tembok.

c. Eccentric, otot menjadi lebih panjang dan tegangan otot bertambah atau kedua ujung otot saling menjauh.40 Kontraksi otot ini terjadi ketika adanya gerakan kontraksi otot memendek, atau sendi ditekuk dengan mengangkat beban, setelah itu beban pada otot diturunkan secara perlahan hingga otot kembali pada ukuran yang sebenarnya. Gerakannya seperti menurunkan dumbbell saat sudah diangkat. Dengan kata lain, kontraksi ini merupakan lanjutan dari gerakan kontraksi otot yang memendek

\section{KERANGKA BERPIKIR}

1. Hubungan konsentrasi terhadap kemampuan shooting pemain

Konsentrasi adalah salah satu bagian dari komponen psikologi yang sangat dibutuhkan dalam olahraga, termasuk sepaknola. Terdapat beberapa area penting dalam psikologi olahraga dalam meningkatkan penampilan pemain, yaitu area konsentrasi dan perhatian. Konsentrasi dapat mengalihkan berbagai stimulus yang datang dan mengganggu pikiran sehingga pemian tetap fokus pada tugas-tugas yang harus dilakukannya. Konsentrasi merupakan hal yang sangat penting untuk dikuasi oleh seorang pemain sepakbola untuk tercapainya hasil yang terbaik bagi pemain maupun tim. Untuk mendapatkan hasil yang maksimal, seorang pemain sepakbola diharapkan memiliki daya konsentrasi yang tinggi, karena dalam pertandingan sepakbola banyak tekanan yang harus dihadapi, seperti tekanan dari lawan, tekanan dari pelatih atau manajer, tekanan dari suporter, dan tekanan waktu yang harus dimanfaatkan dengan baik.

Konsentrasi dapat meningkatkan perhatian sehingga saat mendapat tekanan, perhatian pemain tetap fokus pada hal yang pemain kehendaki. Diharapkan dengan memiliki konsentrasi yang tinggi, pemain mampu menghadapi tekanan-tekanan yang ada. Oleh karena itu, untuk mengetahui hubungan antara tingkat konsentrasi terhadap kemampuan shooting sepakbola pada pemain u-11 tahun Ragunan Soccer School diperlukan suatu tes tingkat konsentrasi dan kemampuan shooting dalam sepakbola. 


\section{Hubungan persepsi kinesetik terhadap kemampuan shooting pemain}

Sebagaimana yang telah diuraikan di atas bahwa persepsi kinestetik merupakan informasi dari erakan tubuh dalam melakukan gerakan setiap cabang olahraga. Kinestetik merupakan proprioceptor yang menggambarkan informasi dari dalam tubuh, seperti dari posisi sendi, kekuatan otot, orientasi di dalam ruang misalnya keadaan terbalik dan sebagainya. Dimana kines itu sendiri berarti suatu gerakan dan thetik sendiri berarti perasaan. Tendangan di lakukan dari satu titik yang berjaran sepuluh meter dari garis gawang. Tendangan dilakukan oleh seorang pemain dalam melakukan tendangan banyak faktor yang ikut mempengaruhi,sehingga tidak sedikit yang gagal dalam melakukan tendangan.

Pada umumnya para pemain sepakbola dalam melakukan tendangan akan memilih suatu sudut yang suit dijangkau oleh seseorang penjaga gawang. Untuk mengarahkan bola ke sudut yang telat ditentukan oleh penendang sendiri akang sangan sulit apabila seseorang penendang pinati belum dapat merasakan atau informasi atas tendangan itu sendiri dari dalam dirinya. Seseorang yang memiliki persepsi kinestetik yang baik tentu akan dengan baik dapat menghasilkan tendangan yang maksimal. Seorang algojo yang melakukan eksekusi tendangan yang memiliki persepsi kinestetik yang baik akan dapt mengarahkan bola ke sudut-sudut yang sulit terjangkau oleh penjaga gawang.

Dengan demikian maka tendangan yang ditugaskan kepadanya akan membuatkan hasil yang baik pula, karena menghasilkan gol kemenangan. Dengan gol yang diciptakan tersebut sudah tentu akan membawa keberuntungan bagi tim mereka. Dengan pemikiran diatas maka dapat diprediksi bahwa seorang penendang yang memiliki persepsi kinestertik yang tinggi akan dapat melakukan tendangan dengan hasil yang baik, atau dengan kata lain bahwa terdapat hubungan yang positif antara persepsi kinestetik dengan hasil tendangan. Semakin tinggi tingkat persepsi kinestetik yang dimiliki oleh seorang pemain maka semakin tinggi pula tingkat keberhasilannya dalam melakukan tedangan.

3. Hubungan konsentrasi dan persepsi kinestetik terhadap kemampuan shooting pemain

Seperti yang telah diuraikan di atas bahwa persepsi kinestetik merupakan informasi dari gerakan tubuh dalam melakukan gerakan setiap cabang olahraga, termasuk sepakbola. Kinestetik merupakan proporio yang menggambarkan informasi dari dalam tubuh, seperti posisi sendi, kekuatan otot, orientasi di dalam ruang misalnya keadaan terbalik dan sebagainya. Dengan memiliki persepsi kinestetik yang baik akan dapat mengarahkan bola ke sudut-sudut yang sulit terjangkau seperi arah sasaran atau posisi target. Disamping faktor persepsi kinestetik, faktor lain yang dapat mempengaruhi dari kemampuan menendang bola atau shooting pemain adalah faktor psikologisnya, yaitu faktor konsentrasi dari pemain.

Konsentrasi yang dimiliki pemain sepakbola sangat berpengaruh terhadap penampilannya disepanjang permainan, terlebih pada saat menentukan arah tendangan agar dapat sesuai dengan arah sasarannya atau targetnya. Dalam melakukan tendangan, konsentrasi dapat meningkatkan perhatian sehingga saat mendapat tekanan, perhatian pemain tetap fokus pada hal yang pemain kehendaki yaitu ketepatan dalam menendang bola.

Berdasarkan pemikiran yang tersebut di atas maka dapat diasumsikan bahwa seorang pemain sepakbola yang memiliki konsentrasi yang tinggi dan memiliki persepsi kinestetik yang tinggi akan dapat melakukan kemampuan menendang atau shooting dengan baik pula, atau dengan kata lain dapat diduga bahwa terdapat hubungan yang positif antara konsentrasi dan persepsi kinestetik dengan kemampuan shooting pemain. Semakin tinggu konsentrasi dan persepsi kinestetik pemain makan semakin tinggi pula tingkat keberhasilan dalam melakukan shooting. 


\section{PENGAJUAN HIPOTESIS}

Sesuai dengan permasalahan yang ada dan berdasarkan kajian teoritis yang berhubungan dengan permasalahan, maka dapat dirumuskan hopotesis penelitian sebagai berikut :

1. Terdapat hubungan yang positif antara konsentrasi terhadap kemampuan menendang bola atau shooting pada pemain u-11 tahun Ragunan Soccer School.

2. Terdapat hubungan yang positif antara persepsi kinestetik terhadap kemampuan menendang bola atau shooting pada pemain u-11 tahun Ragunan Soccer School.

3. Terdapat hubungan yang positif secara bersama-sama antara konsentrasi dan persepsi kinestetik terhadap kemampuan menendang bola atau shooting pada pemain u-11 tahun Ragunan Soccer School

\section{HASIL PENELITIAN}

1. Data Hasil Tes Kemampuan Shooting

Berdasarkan data yang diperoleh dilapangan mengenai kemampuan shooting (Y) yang kemudian diolah secara statistik dengan menggunakan sempel 20 orang di peroleh nilai rata-rata sebesar 33,5 varians sebesar 44,05 simpangan baku sebesar 6,64 modus 34 median sebesar 34 rentang sebesar 28 nilai maksimum 43 dan nilai minimum 15. Selanjutnya data hasil penelitian kemampuan shooting disusun dalam daftar distribusi frekuensi serta dalam bentuk histogram sebagai mana ditunjukkan dalam tabel 1 dan gambar 7 berikut tabel distribusi frekuensinya:

Tabel 1. Distribusi Tabel Kemampuan Shooting

\begin{tabular}{|c|c|c|c|}
\hline Kelas Interval & Nilai Tengah & $\begin{array}{c}\text { Frekuensi } \\
\text { Absolut }\end{array}$ & Frekuensi relatif \\
\hline $14-18$ & 16 & 1 & $5 \%$ \\
\hline $19-23$ & 21 & 0 & 0 \\
\hline $24-28$ & 26 & 2 & $10 \%$ \\
\hline $29-33$ & 31 & 6 & $30 \%$ \\
\hline $34-38$ & 36 & 7 & $35 \%$ \\
\hline $39-45$ & 42 & 4 & $20 \%$ \\
\hline jumlah & & 20 & $100 \%$ \\
\hline
\end{tabular}

Dari data yang terdapat pada tabel 4.2 terlihat bahwa 6 responden memperoleh skor pada kelompok rata-rata sebesar 30\% dari seluruh jumlah responden. 11 responden dengan 55\% dari jumlah responden di atas rata-rata, 3 responden $15 \%$ dari jumlah responden yang memperoleh skor di bawah ratarata. Histogram yang menunjukan skor kemampuan shooting pemain u-11 tahun dapat dilihat pada diagram histogram pada gambar di bawah ini.

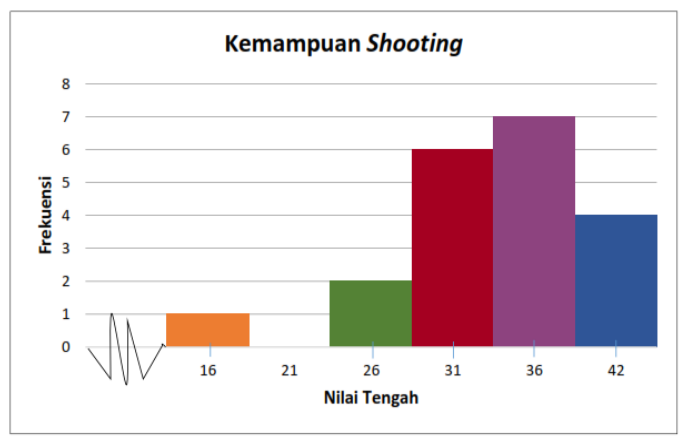

Gambar 7. Grafik Histogram Kemampuan Shooting

Berdasarkan data dari lapangan tentang kemampuan shooting diperoleh rata-rata sebesar 33,5 simpangan baku sebesar 6,64, dan varians 44,05 dari 20 sampel yang mendapatkan skor di atas rata-rata 11 orang, berada pada kelompok rata-rata ada 6 orang dan 3 orang di bawah kelompok rata-rata.

\section{Data Hasil Tes Konsentrasi}

Berdasarkan data yang diperoleh dilapangan mengenai konsentrasi (X1) yang kemudian diolah secara statistik dengan menggunakan sempel 20 orang di peroleh nilai rata-rata sebesar 10,2 varians sebesar 4,59 simpangan baku sebesar 2,14, modus 11, median sebesar 9, rentang sebesar 8, nilai maksimum 13 dan nilai minimum 5 . Selanjutnya data hasil penelitian tes konsentrasi disusun dalam daftar distribusi frekuensi dan histogram sebagai mana ditunjukkan dalam tabel 2 dan gambar 8 Berikut tabel distribusi rekuensinya: 
Tabel 2. Distribusi Tabel konsentrasi

\begin{tabular}{|c|c|c|c|}
\hline Kelas Interval & Nilai Tengah & $\begin{array}{c}\text { Frekuensi } \\
\text { Absolut }\end{array}$ & Frekuensi relatif \\
\hline $4-5$ & 4,5 & 1 & $5 \%$ \\
\hline $6-7$ & 6,5 & 1 & $5 \%$ \\
\hline $8-9$ & 8,5 & 5 & $25 \%$ \\
\hline $10-11$ & 10,5 & 7 & $35 \%$ \\
\hline $12-13$ & 12,5 & 6 & $30 \%$ \\
\hline $14-15$ & 14,5 & 0 & 0 \\
\hline jumlah & & 20 & $100 \%$ \\
\hline
\end{tabular}

Dari data yang terdapat pada tabel 2 terlihat bahwa 7 responden memperoleh skor pada kelompok rata-rata sebesar 35\% dari seluruh jumlah responden. 6 responden dengan $30 \%$ dari jumlah responden di atas rata-rata, 7 responden $30 \%$ dari jumlah responden yang memperoleh skor di bawah rata-rata. Histogram yang menunjukan kelompok skor tes konsentrasi pemain u-11 tahun dapat dilihat pada diagram histogram pada gambar di bawah ini.

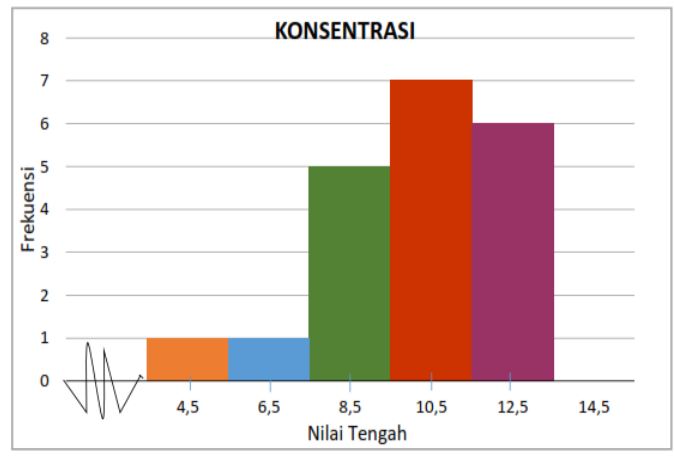

Gambar 7. Grafik Histogram konsentrasi

Berdasarkan data yang diperoleh dari lapangan tentang hasil tes konsentrasi diperoleh rentang skor antara $4-15$. Dari hasil perhitungan rata-rata sebesar 10,2 simpangan baku sebesar 2,14 dan varians 4,59 dari 20 sampel penelitian ternyata yang mendapatkan skor di atas kelompok rata-rata ada 6 orang, yang berada pada kelompok rata-rata 7 orang dan 7 orang di bawah kelompok rata-rata.
3. Data Hasil Tes Persepsi Kinestetik

Berdasarkan data yang diperoleh dilapangan mengenai tes persepsi kinestetik (X2) yang kemudian diolah secara statistik dengan menggunakan sempel 20 orang di peroleh nilai rata-rata sebesar 11,65, varians sebesar 5,29, simpngan baku sebesar 2,30, modus 12 , median sebesar 12 , rentang sebesar 10, nilai maksimum 15 dan nilai minimum 5. Selanjutnya data hasil penelitian tes persepsi kinestetik disusun dalam daftar distribusi frekuensi serta dalam bentuk histogram sebagai mana ditunjukkan dalam tabel 3 dan gambar 9 . berikut tabel distribusi frekuensinya:

Tabel 3. Distribusi Tabel persepsi kinestetik

\begin{tabular}{|c|c|c|c|}
\hline Kelas Interval & Nilai Tengah & $\begin{array}{c}\text { Frekuensi } \\
\text { Absolut }\end{array}$ & Frekuensi relatif \\
\hline $4-5$ & 4,5 & 1 & $5 \%$ \\
\hline $6-7$ & 6,5 & 0 & 0 \\
\hline $8-9$ & 8,5 & 1 & $5 \%$ \\
\hline $10-11$ & 10,5 & 5 & $25 \%$ \\
\hline $12-13$ & 12,5 & 9 & $45 \%$ \\
\hline $14-15$ & 14,5 & 4 & 20 \\
\hline Jumlah & & 20 & $100 \%$ \\
\hline
\end{tabular}

Dari data yang terdapat pada tabel 3 terlihat bahwa 5 responden memperoleh skor pada kelompok rata-rata sebesar $25 \%$ dari seluruh jumlah responden. 13 responden dengan $65 \%$ dari jumlah responden di atas rata-rata, 2 responden $10 \%$ dari jumlah responden yang memperoleh skor di bawah ratarata. Histogram yang menunjukan hasil tes persepsi kinestetik pemain u-11 tahun dapat dilihat pada diagram histogram pada gambar di bawah ini.

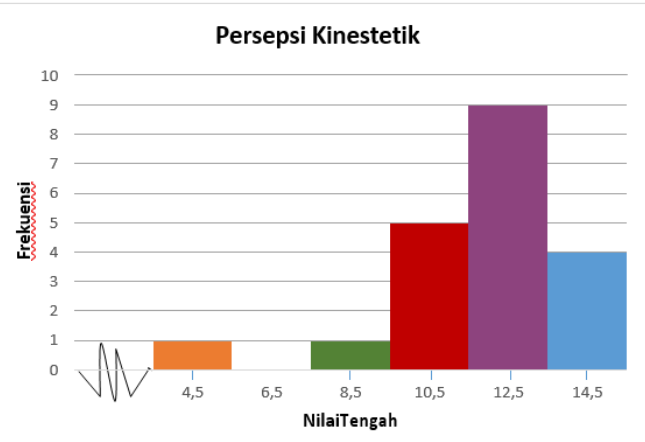

Gambar 8. Grafik Histogram Persepsi Kinestetik 
Berdasarkan data yang dikumpulkan dari lapangan tentang tes persepsi kinestetik diperoleh rata-rata sebesar 11,65 simpangan baku sebesar 2,30 dan varians 5,29 dari 20 sampel penelitian ternyata yang mendapatkan skor di atas kelompok rata-rata ada 13 orang, yang berada pada kelompok rata-rata 28,64 ada 5 orang dan 2 orang di bawah kelompok ratarata.

\section{PENGUJIAN HIPOTESIS}

1. Hubungan Antara Konsentrasi Dengan Kemampuan Shooting Pemain U-11 Tahun Ragunan Soccer School.

Hipotesis yang diajukan dalam penelitian ini adalah terdapat hubungan antara konsentrasi terhadap kemampuan shooting U-11 tahun. Hipotesis ini dapat diartikan bahwa semakin tinggi konsentrasinya, maka semakin tinggi kemampuan shooting pemain U-11 tahun Raguna Soccer School. Sebaliknya adalah semakin rendah tingkat konsentrasi maka semakin rendah pula kemampuan shootingnya. Hipotesis ini secara statistik dapat digambarkan dengan rumusan sebagai berikut: $\mathrm{H} 0: \rho y 1=0 \mathrm{H} 1: \rho y 1 \neq 0$ Hasil pengujian dengan analisis regresi linear sederhana terhadap variabel konsentrasi dalam menjunjangkemampuan shooting pemain U-11 tahun Ragunan Soccer School menghasilkan koefisien arah regresi a sebesar 20, 72 dan konstanta b sebesar 1,25.

Bentuk hubungan antara kedua variabel tersebut dapat dinyatakan oleh persamaan regresi $\mathrm{Y}=20,72+1,25 \mathrm{X} 1$. Uji signifikan dari persamaan $\mathrm{Y}=20,72+1,25 \mathrm{X} 1$ digunakan dengan analisis varians (ANAVA) uji-F. Kriteria signifikan jika Fhitung lebih besar dari Ftabel. Hasil pehitungan koefisien korelasi (ry1) dengan menggunakan product moment dilakukan setelah pengujian signifikan dan uji kelinieran dapat dilihat pada tabel 4 .
Tabel 4: Uji Keberartian Koefisien Variabel Konsentrasi (X1) dengan Kemampuan Shooting (Y)

\begin{tabular}{|l|c|c|c|c|c|}
\hline Korelassl & $a$ & $R$ & $R^{2}$ & thitung & tabeel \\
\hline$X_{1}$ dan $Y$ & 0,05 & 0,505 & 0,2550 & 2,483 & 1,734 \\
\hline
\end{tabular}

Keterangan: $\alpha$ : Taraf signifikan $\mathrm{R}$ : Koefisien Korelasi R2 : Koefisien determinasi

Uji keberartian korelasi antara konsentrasi (X1) dengan kemampuan shooting (Y) pemain U-11 Tahun Ragunan Soccer School sebagai mana terlihat pada tabel 4.9 diperoleh thitung $=2,483$ lebih besar dari pada ttabel $=1,734$ pada taraf signifikan $\alpha=0,05$, jadi dapat disimpulkan bahwa koefisien korelasi ry1 $=0,505$ signifikan. H0 ditolak berarti terdapat hubungan positif antara konsentrasi dengan kemampuan shooting pemain U-11 Tahun Ragunan Soccer School. Hal tersebut dapat disimpulkan bahwa terdapat hubungan yang signifikan antara konsentrasi dengan kemampuan shooting pemain U-11 Tahun Ragunan Soccer School. Hal ini berarti semakin tinggi konsentrasi seorang pemain maka kemampuan shooting sepakbola semakin bagus.

Hasil analisis juga menunjukkan koefisien determinasi sebesar 25,50\% kemampuan shooting pemain U-11 Tahun Ragunan Soccer School yang dijelaskan oleh variabel konsentrasi.

2. Hubungan AntaraPersepsi Kinestetik Dengan Kemampuan Shooting Pemain U-11 Tahun Ragunan Soccer School.

Hipotesis yang diajukan dalam penelitian ini adalah terdapat hubungan antara persepsi kinestetik terhadap kemampuan shooting U-11 tahun. Hipotesis ini dapat diartikan bahwa semakin tinggi persepsi kinestetiknya, maka semakin tinggi kemampuan shooting pemain U-11 tahun Raguna Soccer School. Sebaliknya adalah semakin rendah tingkat persepsi kinestetik maka semakin rendah pula kemampuan shootingnya. Hipotesis ini secara statistik 
dapat digambarkan dengan rumusan sebagai berikut:

$\mathrm{H} 0: \rho y 2=0$

$\mathrm{H} 1: \rho y 2 \neq 0$

Hasil pengujian dengan analisis regresi linear sederhana terhadap variabel persepsi kinestetik dalam menjunjang kemampuan shooting pemain U11 tahun Ragunan Soccer School menghasilkan koefisien arah regresi a sebesar 30,082 dan konstanta b sebesar 0,293. Bentuk hubungan antara kedua variabel tersebut dapat dinyatakan oleh persamaan regresi $\mathrm{Y}$ $=30,082+0,293 \mathrm{X}_{2}$. Uji signifikan dari persamaan $\mathrm{Y}=9,15+0,272 \mathrm{X} 2$ digunakan dengan analisis varians (ANASA) uji-F. Kriteria signifikan jika Fhitung lebih besar dari Ftabel.

Hasil pehitungan koefisien korelasi (ry2) dengan menggunakan product moment dilakukan setelah pengujian signifikan dan uji kelinieran dapat dilihat pada tabel 5 .

Tabel 5. Uji Keberartian Koefisien Variabel Persepsi kinestetik (X2) dengan Kemampuan Shooting (Y)

\begin{tabular}{|c|c|c|c|c|c|}
\hline Koodeas & 0 & $R$ & $R^{2}$ & thitury & tavel \\
\hline KodanY & 0,05 & 0,122 & 0,5213 & 4,48 & 1,734 \\
\hline
\end{tabular}

Keterangan: $\alpha$ : Tara signifikan $\mathrm{R}$ : Koefisien Korelasi R2 : Koefisien determinasi

Uji keberartian korelasi antara
persepsi kinestetik $(\mathrm{X} 2)$ dengan
kemampuan shooting (Y) pemain U-11 Tahun Ragunan Soccer School sebagai mana terlihat pada tabel 5 diperoleh thitung $=4,428$ lebih besar dari pada ttabel $=1,734$ pada taraf signifikan $\alpha=0,05$, jadi dapat disimpulkan bahwa koefisien korelasi ry2= 0,722 signifikan. H0 ditolak berarti terdapat hubungan positif antara persepsi kinestetik dengan kemampuan shooting pemain U-11 Tahun Ragunan Soccer School. Hal tersebut dapat disimpulkan bahwa terdapat hubungan yang signifikan antara persepsi kinestetik dengan kemampuan shooting pemain U-11 Tahun Ragunan Soccer School. Hal ini berarti semakin tinggi persepsi kinestetik seorang pemain maka kemampuan shooting sepakbola semakin bagus.

Hasil analisis juga menunjukkan koefisien determinasi sebesar 52,13\% kemampuan shooting pemain U-11 Tahun Ragunan Soccer School yang dijelaskan oleh variabel persepsi kinestetik.

3. Hubungan Bersama-sama Antara Konsentrasi dan Persepsi Kinestetik Dengan Kemampuan Shooting Pemain U-11 Tahun Ragunan Soccer School.

Hipotesis yang diajukan dalam penelitian ini adalah terdapat hubungan bersama-sama antara konsentrasi dan persepsi kinestetik terhadap kemampuan shooting U-11 tahun. Hipotesis ini dapat diartikan bahwa semakin tinggi tingkat konsentrasi dan persepsi kinestetiknya, maka semakin tinggi kemampuan shooting pemain U-11 tahun Raguna Soccer School. Sebaliknya adalah semakin rendah tingkat konsentrasi dan persepsi kinestetik maka semakin rendah pula kemampuan shootingnya. Hipotesis ini secara statistik dapat digambarkan dengan rumusan sebagai berikut:

$\mathrm{H} 0: \rho y 12=0$

$\mathrm{H} 1: \rho y 12 \neq 0$

Hasil pengujian dengan analisis regresi ganda terhadap pasangan data variabel konsentrasi (X1) dan persepsi kinestetik (X2) dengan kemampuan shooting (Y) pemain U-11 tahun Raguna Soccer School menghasilkan koefisien arah regresi b1 sebesar 1,502 dan konstanta b2 sebesar 0,44, dan konstanta b0 sebesar 13,054. Bentuk hubungan antara kedua variabel tersebut dapat dinyatakan oleh persamaan regresi $\mathrm{Y}=13,054+1,502 \mathrm{X}_{1}+$ $0,44 \mathrm{X}_{2}$. Uji signifikan dari persamaan $\mathrm{Y}=$ $13,054+1,502 \mathrm{X}_{1}+0,44 \mathrm{X}_{2}$ digunakan dengan analisis varians (ANAVA) uji-F. Kriteria signifikan jika Fhitung lebih besar dari Ftabel.

Hasil pehitungan koefisien korelasi (ry12) dengan menggunakan product moment dilakukan setelah pengujian signifikan dapat dilihat pada tabel 6 . 
Tabel 6. Rangkuman Hasil Koefisien

Korelasi Ganda Antara Konsentrasi (X1)

dan Persepsi kinestetik (X2) dengan

Kemampuan Shooting (Y)

\begin{tabular}{|c|c|c|c|c|c|}
\hline Korelasi & $a$ & $R$ & $R^{2}$ & $F_{\text {hiturg }}$ & $F_{\text {tabel }}$ \\
\hline $\begin{array}{l}X_{1} \text { dan } X_{2} \\
\text { dengan } Y\end{array}$ & 0,05 & 0,7148 & 0,511 & 8,793 & 3,59 \\
\hline
\end{tabular}

Keterangan: $\alpha$ : Taraf signifikan $\mathrm{R}$ : Koefisien Korelasi R2 : Koefisien determinasi

Uji keberartian korelasi ganda antara konsentrasi (X1) dan persepsi kinestetik (X2) dengan kemampuan shooting (Y) pemain U-11 Tahun Ragunan Soccer School sebagaimana terlihat pada tabel 6 diperoleh Fhitung $=3,759$ lebih besar dari pada Ftabel $=3,59$ pada taraf signifikan $\alpha=0,05$, artinya

koefisien korelasi ry12 $=0,678$ signifikan. H0 ditolak berarti bahwa terdapat hubungan yang signifikan antara konsentrasi dan persepsi kinestetik dengan kemampuan shooting pemain U-11 Tahun Ragunan Soccer School. Dengan demikian dapat disimpulkan semakin tinggi konsentrasi dan persepsi kinestetik

seorang pemain maka kemampuan shooting sepakbola semakin bagus. Berdasarkan kontribusi (sumbangan) konsentrasi dan persepsi

kinestetik maka semakin tinggi pula kemampuan shooting pemain U-11 tahun Ragunan Soccer School dapat ditentukan dengan koefisien determinasi $\mathrm{R} 2 \mathrm{x}$

$100 \%$. Jadi, besarnya kontribusi konsentrasi dan persepsi kinestetik pemian U11 tahun Ragunan Soccer School sebesar $30,69 \%$.

\section{KESIMPULAN}

Berdasarkan analisis data, maka dapat disimpulkan bahwa :

1. Terdapat hubungan yang positif antara konsentrasi terhadap kemampuan menendang bola atau shooting pada pemain u-11 tahun Ragunan Soccer School.

2. Terdapat hubungan yang positif antara persepsi kinestetik terhadap kemampuan menendang bola atau shooting pada pemain u-11 tahun Ragunan Soccer School.

3. Terdapat hubungan yang positif secara bersama-sama antara konsentrasi dan persepsi kinestetik terhadap kemampuan menendang bola atau shooting pada pemain u-11 tahun Ragunan Soccer School.

\section{SARAN}

Berdasarkan hasil penelitian yang telah dilakukan, maka pada kesempatan ini peneliti ingin memberikan hasil saran sebagai berikut :

Bagi pemain senantiasa melatih konsentrasi dan persepsi kinestetik sehingga dapat mencapai kemampuan shooting yang maksimal.

1. Bagi pelatih pemain $\mathrm{u}-11$ tahun Ragunan Soccer School agar meneliti komponen fisik lainnya sebagai upaya meningkatkan prestasi serta kemampuan shooting dan dapat dipakai sebagai acuan pembuatan program latihan pada pemain u-11 tahun Ragunan Soccer School.

2. Untuk pelatih mencari atlet sepak bola dapat menggunakan variabel yang telah diuji sebagai scouting talent untuk bakat atlet atau calon atlet sehingga tidak membuang waktu melatih atlet yang tidak berbakat.

3. Dalam skripsi ini masih banyak kekurangan, untuk itu bagi peneliti selanjutnya hendaknya mengembangkan dan menyempurnakan instrumen penelitian ini. 


\section{DAFTAR PUSTAKA}

Arikunto, Suharsimi. 2002. Metodologi Penelitian. 2002

Avry, Yvon, Marco Bener dkk. 2014. FIFA Education and Technical Development Department, Switzerland: FIFA Production

Baihaqi, Cipta. 2013. Hubungan Kekuatan Otot Tungkai, Koordinasi MataKaki, dan Persepsi Kinestetik dengan Kemampuan Dasar Sepak Bola. Tesis. Jakarta: UNJ

Batty, Eric C. 2003. Latihan Sepakbola Metode Baru Serangan. Bandung: Pioner Jaya

Beltasar, Tarigan. 2001. Pendekatan Kemampuan Taktis Dalam Pembelajaran SepakBola. Jakarta: Depdiknas, Direktorat Jenderal Pendidikan Dasar dan Menengah. Bekerjasama Dengan Direktorat Jenderal Olahraga

Djamarah, Syaiful Bahri. 2011. Psikologi Belajar, Jakarta: PT. Rineka Cipta

Efendi, C. 2009. Faal Sel, Cairan Tubuh, Saraf Tepi, dan otot. Surabaya: Departemen Ilmu Faal UNAIR

Fanny, Nabilatul. Analisi Pengaruh Kebisingan Terhadap Tingkat Konsentrasi Kerja Pada Tenaga Kerja di Bagian Proses PT. Iskandar Indah Printing Textile Surakarta, Infokes Vol. 5 No. 1 Febuari 2015, ISSN: $2086-2628$

Gallague, David L, Understanding Motor Development Infants, Children, Adolescents, Adult. New York: McGraw Hill

Gardner, Howard. 2008 New Horizon: Multiple Intelligence. New York: Basic Book Publication

Gunarsa, Singgih D. 2008. Psikologi Olahraga Prestasi, Jakarta: Gunung Mulia

Hakim, Thursan. 2003. Mengatasi Gangguan Konsentrasi, Jakarta: Puspa Swara Komarudin. 2013. Psikologi Olahraga. Bandung: PT Remaja Rosdakarya Offset

Soekatamsi. 2000. Teknik Dasar Bermain Sepak Bola. Solo: Tiga Serangkai
Sucipto. 2000. Sepakbola. Departmen Pendidikan Nasional

Sudjana. 2005. Metode Statistika. Bandung: Grassindo

Sugiyanto. 2002. Pertumbuhan dan Perkembangan Gerak Jakarta: KONI Pusat Pendidikan dan Penataran

Sugiyono. 2015. Metode Penelitian Pendidikan Pendekatan Kuantitatif, Kualitatif dan RnD. Bandung: Alfabeta

Sukadiyanto. 2006. Majalah Olahraga. Yogyakarta: UNY

Pusat Pengembangan Kualitas Jasmani, Depdiknas. Buletin Kesegaran Jasmani Edisi 17/Th.XI/Juli 2005

Walgito, Bimo. 2010. Pengantar Psikologi Umum. Yogyakarta: Andi Offset 